\title{
DIFFERENCES IN REPORTED FIRM PERFORMANCE BY GENDER: DOES INDUSTRY MATTER?
}

\author{
JANE L. SWINNEY \\ 445 HES Building, Oklahoma State University \\ Stillwater, OK 74078, USA \\ RODNEY C. RUNYAN \\ College of Hospitality, Retail and Sport Management \\ University of South Carolina, Columbia, SC 29208, USA \\ PATRICIA HUDDLESTON \\ Department of Retailing, Michigan State University \\ East Lansing, MI 48824, USA \\ Received December 2005 \\ Revised March 2006
}

\begin{abstract}
Business performance results were collected from small business entrepreneurs in one Mid-western state operating in the retail and services industries. These industries account for more than 80 percent of female entrepreneurs' fields of operation. The pattern of reported firm performance between the genders indicated that male entrepreneurs with a high school education reported the highest firm performance scores overall. Female entrepreneurs with a college degree reported the highest firm performance scores among female entrepreneurs. Aspiring female entrepreneurs need to be encouraged to complete higher education as it translates into strong future business performance.
\end{abstract}

Keywords: Small business; firm performance; gender; retail/service industries.

\section{Introduction}

The number of female-owned businesses is growing globally yet, despite their growth, research findings indicate that firm performance is higher in male-owned firms than femaleowned firms (Cuba et al., 1983; Hisrich and Brush, 1984; Loscocco et al., 1991). Multinational studies report the effects of gender on small business performance in countries around the globe (Fasci and Valdez, 1998; Schmidt and Parker, 2003; Singh et al., 2001). Small businesses operating in the same industry perform differently when owned by a female than those owned by a male (Losocco and Robinson, 1991). Losocco et al. (1991) suggest that the difference in performance may be due to individual differences brought to the small business, or differences in industry sector. Fasci and Valdez (1998) recommended that as the body of research on gender differences expands it should be conducted industry by industry due to differences in economic and business environments between industries. This study 
extends gender-based research on business performance through an examination of firm performance in the retail and service industries, which account for 83.3 percent of female owned businesses in the U.S.

Retail and service sectors of the U.S. economy comprise more than 50 percent of all small firms (SBA, 2003). In the United States, more than 83 percent of female-owned businesses operate in the retail and service sectors while only 60 percent of male-owned firms operate in these two sectors (SBA, 2003). According to Schmidt and Parker (2003), this heavy concentration of female owners in these sectors is likely to continue. Service and retail firms face few barriers to entry, are intensely competitive and experience a high business failure rate (Kirchoff, 1994). Kirchoff refers to these types of businesses as the "economic core" of industries accessible to females who may lack financial support or access to capital. Skinner's (1992) study of entrepreneurs in the retail trades found that both male and female entrepreneurs reported themselves a success in their business although male entrepreneurs had more formal education and generated higher revenues than female entrepreneurs. Our research question was whether performance of firms operating in the retail and services sectors would be significantly different when a male or a female owned a firm.

Our literature review covers employment contributions of small business in the U.S. economy, women owned businesses in the U.S., educational level of entrepreneurs, industry business concentrations between the genders, and performance within gender dominated businesses. We present nine hypotheses; explain our methodology and present results of entrepreneurial responses for the complete sample as well as separately by gender-dominant business type within the retail and services sectors. This approach allows for an in-depth examination of the differences by business type, as well as by owner-gender dominance. The results are used to discuss differences in firm performance based on gender as well as education levels. Patterns of performance reporting are discussed followed by suggestions for extending the research base on small firm performance.

\section{Employment Contributions of Small Business in the United States Economy}

Small business is an important part of the United States economic base. A small business is defined by the Small Business Administration (SBA) as one that is independently owned and operated but is not dominant in its field of operation. There were more than 22 million small businesses in the U.S. in 2003, accounting for 99.7 percent of employer businesses (SBA, 2003). Small businesses with fewer than 20 employees accounted for 27 percent of U.S. job gains during 2000-2001 (SBA, 2003).

\section{Women-Owned Businesses in the United States}

It is projected that women will account for 55 percent of the increase in the total labor force from 2002-2012 (U.S. Department of Labor, 2005). Revenues from businesses owned by women generated more than \$2.5 trillion in 2004 (Center for Women's Business Research, 2005). Self-employment by women represented 37.4 percent of the self-employed persons in the United States for 2004, up from 31.5 percent in 2003 (SBA, 2003). Women own over 35 percent of all businesses in the U.S. (U.S. Women's Chamber of Commerce, 2005), 
and have an average national growth-rate of 3.2 percent (SBA, 2003). Most women-owned businesses in the United States (87 percent) have receipts of less than $\$ 50,000$ annually (SBA, 2003). Kalleberg and Leicht (1991) found male-owned firms reporting mean annual earnings 15 percent higher than earnings in female-owned firms. In a study of male and femaleowned accounting practices, average earnings from female-owned firms were 51 percent of the average earnings of the male-owned firms (Fasci and Valdez, 1998). Similar findings were reported by Craig, Martin and Horridge (1997) and Loscocco et al. (1991) in their studies of retail and service firms. The growth in the number of women-owned businesses comes despite 27 percent of women business owners having a high school education or less compared to 24 percent of male business owners.

\section{Educational Level of Entrepreneurs}

Education has been suggested as an important variable influencing entry and mobility into a market, as well as access to capital (U.S. Department of Labor, 2005). Evidence indicates that education affects self-employment entry in certain industrial sectors (Bates, 1995), and more highly educated owners are more likely to establish lasting firms (Bates, 1997). Education, acomponent of human capital the owners bring to their business, has been identified as a variable affecting success of small businesses, with specific references made to skills and experiences of the owners (Bender, 1980; Loscocco et al., 1991; Powell and Ansic, 1997; Wirth, 2001). The extant literature often cites education as a factor impacting firm performance. Craig et al. (1997) stated that businesses are directly influenced by the values and philosophies of the business owners. An individual's values are often developed through their formal education process, suggesting that educational level might have an impact on small business operations and performance.

An individual's level of formal education also reflects cognitive abilities and qualities, including a tolerance for ambiguity (Dollinger, 1985). The highest levels of formal education are associated with an ability to process information and to discriminate between wide varieties of alternatives (Dollinger, 1985). In Skinner's study of entrepreneurs (1992), male entrepreneurs had more formal education than female entrepreneurs. Females with more education may have increased chances for success among female entrepreneurs but the broader question is whether one's education influences entrepreneurial self-reported firm performance regardless of gender.

\section{Industry Business Concentrations between the Genders}

The Small Business Administration in 2003 found male-owned businesses occurred across a variety of industries, while female-owned businesses were highly concentrated in the service and retail sectors. Women-owned proprietorships in the U.S. are concentrated in service businesses (60.7 percent), wholesale and retail trade (22.6 percent), followed by finance, insurance and real estate ( 9 percent), and mining, manufacturing and construction (4.3 percent). Male owned businesses are much less concentrated with 45 percent in services, 21 percent in mining, manufacturing and construction, 15 percent in wholesale and retail trade 
and 8 percent in finance, insurance and real estate (SBA, 2003). The Small Business Office of Advocacy (2003) reports nearly two-thirds (62 percent) of the income for women-owned businesses is generated in the services sector while 45 percent of male-owned businesses generate income in the services sector. Wholesale and retail trade businesses account for 22 percent of the income for female-owned businesses and 15 percent of the income for male-owned businesses.

The concentration of female-owned businesses in the highly competitive, low-growth services and retail industries may explain a relative lack of success or performance for these firms (Loscocco et al., 1991). Thus the very concentration of female-owned businesses in the service and retail sectors can impede their performance compared to male-owned firms that are not so highly concentrated in low-growth competitive industries. Loscocco et al. (1991) found that firm size mediated most of the difference in performance between genders and concluded women's lower performance levels as small business entrepreneurs can be explained by their tendency to operate smaller businesses in less-profitable industries.

Fasci and Valdez (1998) suggested an industry specific approach in examining business performance with respect to male-and female-owned businesses. Such a focus could address the variance in economic and business environments from one industry to another (Fasci and Valdez, 1998). This leads to the need to focus on industry rather than firms.

\section{Performance within Gender Dominated Businesses}

The small single owner firm must rely on the characteristics of one primary individual responsible for business decisions. This individual may not bring a balanced approach to the business decisions required of successful small firms. Litz and Folker (2002) found a gender balanced management team had more impact on firm performance than a single gender management organization, thus they proposed a positive link between diverse management gender and firm performance. Lower performance in female owned firms can often be attributed to females' preference for lower risk (Hudgens and Fatkin, 1985; Levin et al., 1988; Sexton and Bowman-Upton, 1990). Differences in socialization experiences may result in women lacking the attitudes (e.g., risk-taking and internal locus of control) that are deemed important to small business performance (Marini and Brinton, 1984).

Veroff (1977), Travis (1982), and Poole and Langan-Fox (1993) investigated the selfrated career success of males and females. In each study females used a different schema than males to evaluate personal career success. The females rated their career success more in terms of the process rather than the level of work they were doing. Males, on the other hand, evaluated personal career success in a more competitive manner; results counted more than the process. If personal career success is evaluated differently for the genders, it may be that the genders evaluate firm performance differently as well. No research has been found that analyzed the possible interactive effects of owner gender and education on firm performance in traditionally female-owner dominated business types. The present study is unique in that it reports findings on the firm performance of both male- and female-owned businesses operating in the service and retail industries, where more than three-fourths of female entrepreneurs operate. 


\section{Research Question and Hypotheses}

From previous studies indicating the impact of gender on firm performance and recognition of differences in formal educational levels between male and female entrepreneurs, we investigated the gender and education level of the entrepreneur as possible influences on small firm performance within the retail and services sectors. We were additionally interested in examining firm performance of male- or female-owner dominant business types within the retail and services sectors. The following hypotheses guided the research.

\subsection{Hypotheses}

H1a: There will be a significant difference in reported performance based on education. Owners with higher levels of education will report higher levels of firm performance.

$\mathrm{H} 1 \mathrm{~b}$ : There will be a significant difference in reported firm performance based on owner gender. Male owners will report higher performance levels than female owners.

$\mathrm{H} 1 \mathrm{c}$ : There will be no significant difference in reported performance based on the interaction of education and gender. Males will report higher levels of performance regardless of educational level.

$\mathrm{H} 2 \mathrm{a}$ : There will be a significant difference in firm performance based on education in female-owner dominated business types. Owners with higher levels of education will report higher levels of performance than owners with lower levels of education.

$\mathrm{H} 2 \mathrm{~b}$ : There will be a significant difference in firm performance based on owner gender in female-owner dominated business types. Female owners will report higher levels of firm performance than males.

$\mathrm{H} 2 \mathrm{c}$ : In female-owner dominated business types, there will be a significant difference in firm performance based on the interaction of education and gender. Female owners with high levels of education will report higher firm performance than male owners with lower levels of education.

$\mathrm{H} 3 \mathrm{a}$ : There will be no significant difference in firm performance based on owner education in male-owner dominated business types.

H3b: There will be a significant difference in firm performance based on owner gender in male-owner dominated business types. Male owners will report higher firm performance than female owners.

$\mathrm{H} 3 \mathrm{c}$ : In male-owner dominated business types, the interaction of education and gender will have no effect on firm performance. Males will report higher levels of firm performance than females, regardless of education levels.

\section{Methodology}

\subsection{Sampling procedure}

This study was restricted to firms in small-to-medium (less than 30,000 population), nonurban rural communities. The USDA defines these communities as being located more than 30 miles from a metropolitan statistical area (MSA). This study utilized a judgment sample that is a non-probability sample (also referred to as purposive), the elements of which are 
handpicked to serve the purpose of the study (Churchill and Iacobucci, 2002). A total of 14 downtowns within one midwestern state agreed to participate; only 11 followed through and participated.

Dillman (2000) offers many suggestions to help increase response rates in mail surveys. Since this study was not a mail survey, several of his suggestions were adapted to this study. The first was the process of pre-notification. The second was offering an incentive. The Downtown Development Authority (DDA) director was contacted and asked to denote stores located in the traditional central business district. Following agreement of the DDA director to participate in the study, the director became a "champion" of the research project. This entailed announcing the study to downtown business owners (pre-notification), supporting the research as important to the downtown (incentive), and requesting their participation. The director also set a date for distribution and a date for picking up the completed surveys.

All surveys were disseminated and collected over a three-week period. A total of 1108 surveys were disseminated in the 11 towns. A total of 272 were returned, for an initial response rate of 25 percent. Of those 272, five were deemed unusable for different reasons, including being completely blank. This provided a final response rate of 24.1 percent.

\subsection{Instrument}

Often, revenues or profits are used as performance measures but small businesses are generally unwilling to report net dollar revenues or profit percentages. In the study reported here, less than half of the sample provided revenue figures. According to Venkatraman and Ramanujam (1986), self-reported levels of performance are generally highly correlated with revenue and profit. Therefore in the current research, performance measures were subjective measures. Performance was measured by owner response to questions about their firm's performance using a 1-7 scale where 7 represented an excellent report of the firm's performance. The three questions asked the owner to rate their: (1) firm's performance during the previous year, (2) firm's performance relative to major competitors, (3) firm's performance relative to other businesses like theirs in the industry. Mean responses were summed and averaged to determine each respondent's reported performance score. These three subjective questions regarding business performance yielded a Cronbach's alpha of 0.88 . Though we used a subjective measure of performance, we found performance scores significantly correlated $(r=0.334, \mathrm{p}<0.01)$ with reported net profit percent. Demographic information including entrepreneurial educational level and gender was also collected.

\subsection{Sample description}

The sample consisted of 267 owner/managers of small businesses within the Central Business District of downtowns in 11 communities in a mid-western state. The populations of these communities ranged from 2,972 to 25,496. In the sample, 78 percent of the businesses had been in existence for seven or more years. In general, the firms fit the profile of a small business as measured by number of full and part-time employees. Forty-four percent of the respondents reported having two or fewer full-time employees, including themselves. Over 65 percent of the respondents reported employing five or fewer part-time employees, 
including themselves. A detailed account of the sample characteristics can be found in Table 1.

\subsection{Owner-dominance classification}

In order to examine the education, gender and gender/education interaction effect on firms by dominant gender ownership, we first had to classify each of the 19 possible business types into one of two groups, dominated by either male or female owners. Sixty-six percent

Table 1. Sample characteristics of entrepreneurs $(n=267)^{*}$.

\begin{tabular}{|c|c|c|c|c|c|c|}
\hline \multirow{2}{*}{$\begin{array}{c}\text { Sample } \\
\text { Characteristic }\end{array}$} & \multicolumn{3}{|c|}{ Frequency } & \multicolumn{3}{|c|}{ Percentage } \\
\hline & $\begin{array}{l}\text { Complete } \\
\text { Sample }\end{array}$ & $\begin{array}{c}\text { Male } \\
\text { Owner } \\
\text { Dominated } \\
\text { Businesses }\end{array}$ & $\begin{array}{c}\text { Female } \\
\text { Owner } \\
\text { Dominated } \\
\text { Businesses }\end{array}$ & $\begin{array}{l}\text { Complete } \\
\text { Sample }\end{array}$ & $\begin{array}{c}\text { Male } \\
\text { Owner } \\
\text { Dominated } \\
\text { Businesses }\end{array}$ & $\begin{array}{c}\text { Female } \\
\text { Owner } \\
\text { Dominated } \\
\text { Businesses }\end{array}$ \\
\hline \multicolumn{7}{|l|}{ Gender } \\
\hline Male & 139 & 42 & 17 & 52.0 & 75 & 29.8 \\
\hline Female & 120 & 14 & 40 & 44.9 & 25 & 70.1 \\
\hline \multicolumn{7}{|l|}{ Age } \\
\hline 40 or less years & 47 & 10 & 9 & 17.6 & 23.3 & 19.6 \\
\hline $41-50$ years & 69 & 13 & 17 & 25.8 & 30.2 & 37.0 \\
\hline 51 years and over & 91 & 20 & 20 & 34.1 & 46.5 & 43.5 \\
\hline \multicolumn{7}{|l|}{ Education } \\
\hline High school graduate & 35 & 8 & 11 & 13.1 & 14.5 & 19.6 \\
\hline Some college & 73 & 18 & 20 & 27.3 & 32.7 & 35.7 \\
\hline University graduate & 112 & 20 & 29 & 41.9 & 36.4 & 51.8 \\
\hline Graduate school & 28 & 9 & 5 & 10.5 & 16.4 & 16.1 \\
\hline \multicolumn{7}{|c|}{ Years business has existed } \\
\hline 6 or less & 49 & 6 & 11 & 18.3 & 11.3 & 19.3 \\
\hline $7-15$ & 55 & 11 & 14 & 20.6 & 20.8 & 24.6 \\
\hline $16-30$ & 75 & 12 & 20 & 28.1 & 22.6 & 35.1 \\
\hline 31 or more & 78 & 24 & 12 & 29.2 & 45.3 & 21.1 \\
\hline \multicolumn{7}{|l|}{ Years in downtown } \\
\hline 6 or less & 74 & 9 & 16 & 27.7 & 17.3 & 29.1 \\
\hline $7-15$ & 56 & 14 & 15 & 21.0 & 26.9 & 27.3 \\
\hline $16-30$ & 66 & 10 & 15 & 24.7 & 19.2 & 27.3 \\
\hline 31 or more & 52 & 19 & 9 & 23.2 & 36.5 & 16.4 \\
\hline \multicolumn{7}{|l|}{ Full-time employees } \\
\hline None & 27 & 5 & 7 & 10.1 & 12.2 & 16.3 \\
\hline $1-2$ & 90 & 13 & 24 & 33.7 & 31.7 & 55.8 \\
\hline $3-5$ & 54 & 13 & 10 & 20.2 & 31.7 & 23.3 \\
\hline 6 or more & 28 & 10 & 2 & 10.5 & 24.4 & 4.7 \\
\hline \multicolumn{7}{|l|}{ Part-time employees } \\
\hline None & 24 & 8 & 4 & 9.0 & 17.4 & 7.7 \\
\hline $1-2$ & 86 & 23 & 24 & 32.2 & 50 & 46.2 \\
\hline $3-5$ & 65 & 9 & 15 & 24.3 & 32.6 & 28.8 \\
\hline 6 or more & 55 & 6 & 9 & 20.6 & 13.0 & 17.3 \\
\hline
\end{tabular}

*Totals do not include non-respondents. 
of the business owners in each of the 19 possible business types had to be of one gender for the business to be classified into one of the two owner-gender groups. For the present study, if a business type did not have at least 66 percent of owners in one gender then the business was excluded from further analysis on owner-gender dominance. This figure represented a clear majority of the owners in one gender and was comparable with Brown and Ridge (2002) who used 60 percent male employees to classify a business as male dominated.

\section{Analysis and Results}

Our analysis was conducted in three phases. The first phase examined responses from all 267 respondents to test Hypotheses la-c. In phase two, we separated the sample by dominant owner-gender business type and analyzed responses within the female-owner dominated business types (Hypotheses $2 \mathrm{a}-\mathrm{c}$ ), followed by phase three, in which we examined responses within the male-owner dominated business types (Hypotheses 3a-c). Statistical analyses were restricted to analysis of variance and reported mean performance scores for each gender and business type. The intent of the research was to examine the possible education/gender interaction effect on performance of firms operating in the retail and service sectors. Additionally we were interested in examining firm performance of male and female-owner dominant business types.

\subsection{Phase one analysis}

Responses from all respondents were first analyzed to see whether owner education had a significant effect on reported firm performance. We then analyzed responses to see whether owner gender had a significant effect on firm performance. ANOVA results indicated that education did not significantly affect firm performance $(\mathrm{F}=2.266, \mathrm{p}<0.082)$ but gender did have a statistically significant effect $(\mathrm{F}=5.801, \mathrm{p}<0.017)$. Thus we rejected H1a and accepted H1b. All responses were next analyzed for the possible interaction of gender and education on firm performance using a 2 (gender) $\times 4$ (educational level) factorial design. Results showed a significant interaction effect of gender/education on firm performance $(\mathrm{F}=4.808, \mathrm{p}<0.003)$. H1c was rejected. Table 2 presents the results of the factorial analysis. Table 3 presents mean performance scores for all male and female owners by educational level.

Table 2. Summary of two way analysis of variance for gender and education.

\begin{tabular}{lccc}
\hline Dependent Variable: & Business & Performance \\
\hline Variable & df & MS & F \\
Gender & 1 & 7.029 & $5.801^{*}$ \\
Education & 3 & 2.745 & 2.266 \\
Gender $\times$ Education & 3 & 5.825 & $4.808^{*}$ \\
\hline $\mathrm{p}<0.05$. & & &
\end{tabular}


Table 3. Mean performance score by gender and education for total sample.

\begin{tabular}{lllcr}
\hline Gender & \multicolumn{1}{c}{ Education } & Mean & Std. Deviation & N \\
\hline Male & High School & 5.5606 & 1.00468 & 22 \\
& Some College & 5.1979 & 1.12915 & 32 \\
& College Graduate & 4.9359 & 1.05479 & 65 \\
& Master/PhD. & 5.3333 & 0.77349 & 14 \\
& Overall & 5.1441 & 1.05505 & 133 \\
Female & High School & 5.0444 & 1.28401 & 15 \\
& Some College & 5.2308 & 1.06829 & 39 \\
& College Graduate & 5.2370 & 1.04597 & 45 \\
& Master/PhD. & 3.9359 & 1.65487 & 13 \\
& Overall & 5.0580 & 1.22448 & 112 \\
& High School & 5.3514 & 1.13840 & 37 \\
& Some College & 5.2160 & 1.08832 & 71 \\
& College Graduate & 5.0591 & 1.05689 & 110 \\
& Master/PhD. & 4.6605 & 1.43854 & 27 \\
& Overall & 5.1048 & 1.13407 & 245 \\
\hline
\end{tabular}

\subsection{Preparation for phase two and three analysis}

Based on our owner dominant classification, 114 of the 267 total businesses were included in further analyses of owner-gender dominance. Fifty-seven businesses were classified as female-owner dominant and 57 were classified as male-owner dominant. These ownergender dominated businesses were comprised of 46 retail businesses (42.6 percent), 59 service businesses (51.8 percent) and 9 were real estate businesses. Beauty shops and barbershops were included as service businesses. Table 4 provides the owner-gender distribution by business category for the sample.

\subsection{Phase two analysis: Performance score results by female-dominant owner business types}

ANOVA was used to test for education, gender and education/gender interaction effects on firm performance for the 57 businesses dominated by female owners (see Table 5). For businesses operating as a female-owner dominated business type, education alone and gender alone had no significant effect on firm performance. The education/gender interaction effect on performance score was not significant $(\mathrm{F}=1.205, \mathrm{p}<0.31)$. Thus H2a, H2b and $\mathrm{H} 2 \mathrm{c}$ were not supported. In the female-owner dominant business types including real estate firms, retail clothes and shoes, retail cards and gifts, retail computers, electronics and beauty shops there was no significant difference in performance levels reported between male- and female-owned businesses regardless of gender, education level or the interaction of gender and education.

\subsection{Phase three analysis: Performance score results by male-dominant owner business types}

Table 5 presents complete results for both owner-gender dominant owner business types. For the 57 male-owner dominated businesses, education alone and gender alone had no effect on 
Table 4. Owner-gender distribution by business category.

\begin{tabular}{|c|c|c|}
\hline Business Category & Frequency & Percent \\
\hline \multicolumn{3}{|l|}{ Service } \\
\hline Total Category & 100 & 37.5 \\
\hline Male & 58 & 41.7 \\
\hline Female & 40 & 33.3 \\
\hline Male Owner Dominated & 44 & 77.2 \\
\hline Female Owner Dominated & 15 & 26.3 \\
\hline \multicolumn{3}{|l|}{ Retail } \\
\hline Total Category & 66 & 24.7 \\
\hline Male & 31 & 22.3 \\
\hline Female & 35 & 29.2 \\
\hline Male Owner Dominated & 13 & 22.8 \\
\hline Female Owner Dominated & 33 & 57.9 \\
\hline \multicolumn{3}{|l|}{ FIRE(Finance/Real Estate) } \\
\hline Total Category & 9 & 3.4 \\
\hline Male & 3 & 2.2 \\
\hline Female & 6 & 5.0 \\
\hline Male Owner Dominated & - & \\
\hline Female Owner Dominated & 9 & 15.8 \\
\hline \multicolumn{3}{|l|}{ Other } \\
\hline Total Category & 76 & 28.5 \\
\hline Male & 43 & 30.9 \\
\hline Female & 31 & 25.8 \\
\hline Male Owner Dominated & - & - \\
\hline Female Owner Dominated & - & - \\
\hline \multicolumn{3}{|l|}{ Total } \\
\hline Total Category & $251 *$ & $94.0^{*}$ \\
\hline Male & 139 & 52.1 \\
\hline Female & 120 & 44.9 \\
\hline Male Owner Dominated & 57 & 21.3 \\
\hline Female Owner Dominated & 57 & 21.3 \\
\hline
\end{tabular}

*Totals do not include non-respondents.

Table 5. Summary of two-way analysis of variance for owner-gender and education.

\begin{tabular}{|c|c|c|c|c|c|c|c|c|}
\hline \multirow[b]{3}{*}{ Source } & \multicolumn{7}{|c|}{ Dependent Variable: Performance } & \\
\hline & \multicolumn{4}{|c|}{$\begin{array}{l}\text { Female Owner Dominated Business Type } \\
\qquad \mathrm{N}=57\end{array}$} & \multicolumn{4}{|c|}{$\begin{array}{l}\text { Male Owner Dominated Business Type } \\
\qquad N=57\end{array}$} \\
\hline & df & MS & $\mathrm{F}$ & $\mathrm{p}$ & df & MS & $\mathrm{F}$ & $\mathrm{p}$ \\
\hline Education & 3 & 1.109 & 0.775 & 0.514 & 3 & 1.715 & 2.044 & 0.121 \\
\hline Gender & 1 & $6.733 \mathrm{E}-02$ & 0.047 & 0.829 & 1 & $5.217 \mathrm{E}-02$ & 0.062 & 0.804 \\
\hline Edu * Gender & 2 & 1.724 & 1.205 & 0.309 & 3 & 0.687 & 0.819 & 0.490 \\
\hline
\end{tabular}

$\mathrm{N}=114$.

firm performance. The education/gender interaction effect on reported performance score was not significant $(\mathrm{F}=0.819, \mathrm{p}<0.49)$. The level of education and the gender of the owner operating a firm in the male-owner dominated business types, which included financial services, personal services, bars, sales and repair services, retail housewares and hardware, 
retail sporting goods, and barber shops had no significant effect on firm performance. H3a and $\mathrm{H} 3 \mathrm{c}$ were supported, but $\mathrm{H} 3 \mathrm{~b}$ was rejected.

Separating the responses into gender-owner dominant business types did not produce significant effects for education or gender or the interaction of the two on firm performance. However the pattern of performance reporting within the female and male owner dominated business types provides avenues for future research on owner-gender and small business performance. These patterns are summarized below. While gender did have a statistically significant effect on firm performance, a limitation of the analysis on reported firm performance must be acknowledged. Reported firm performance was determined by calculating the mean response to questions in which the owner self evaluated their perception of their firm's performance relative to the previous year, to other similar businesses in their community and to the overall industry in which they operate. Although Venkatraman and Ramanujam (1986) found such measures correlated with traditional objective performance measures of income and profit, subjective measures may promulgate bias of the business owner or be misinterpreted by the owner. The subjective measures really may capture owner's satisfaction with business outcomes and not actual achievement of objective performance outcomes. The reported performance scores must be viewed with these limitations recognized. Despite limitations, examination of patterns of reported firm performance between respondents is an area of entrepreneurial research needing further study.

\subsection{Patterns of reported performance in female-owner dominated business types}

Mean performance scores by owner-gender dominance and education are provided in Table 6 . Reported performance mean scores varied by educational level and gender in the

Table 6. Mean performance scores by owner-gender dominance and educational level.

\begin{tabular}{|c|c|c|c|c|c|c|}
\hline \multirow[t]{3}{*}{ Education } & \multicolumn{6}{|c|}{ Female Owner Dominated Businesses } \\
\hline & \multicolumn{3}{|c|}{ Male } & \multicolumn{3}{|c|}{ Female } \\
\hline & M & SD & $\mathrm{N}$ & M & SD & $\mathrm{N}$ \\
\hline High school & 5.5333 & 1.16905 & 5 & 5.0556 & 1.28956 & 6 \\
\hline Some college & 5.1667 & 1.24722 & 8 & 4.9722 & 1.08673 & 12 \\
\hline College graduate & 4.3750 & 1.70171 & 4 & 5.2917 & 1.01013 & 16 \\
\hline Graduate school & . & . & & 4.3667 & 1.45488 & 5 \\
\hline Total & 5.0882 & 1.32565 & 17 & 5.0385 & 1.12875 & 39 \\
\hline \multirow[t]{3}{*}{ Education } & \multicolumn{6}{|c|}{ Male Owner Dominated Businesses } \\
\hline & \multicolumn{3}{|c|}{ Male } & \multicolumn{3}{|c|}{ Female } \\
\hline & M & SD & $\mathrm{N}$ & M & SD & $\mathrm{N}$ \\
\hline High school & 5.5333 & 0.96032 & 5 & 4.7778 & 1.34715 & 3 \\
\hline Some college & 5.5758 & 0.70065 & 11 & 6.0000 & 0.57735 & 7 \\
\hline College graduate & 4.9412 & 1.00854 & 17 & 5.0000 & 1.20185 & 3 \\
\hline Graduate school & 5.3810 & 0.93152 & 7 & 6.0000 & . & 1 \\
\hline Total & 5.2667 & 0.92512 & 40 & 5.5238 & 0.99326 & 14 \\
\hline
\end{tabular}

$\mathrm{N}=110$. 
female-owner dominated business types. Reported performance in female-owner dominated businesses was highest for male owners with a high school education (5.53) and lowest for both female owners with a graduate degree and male owners with a college degree (4.37). The level of reported firm performance for the males operating in the female dominated business types declines as the owner completes more education. For the female owners, the college graduate reports the highest performance, followed by females with a high school education and is lowest among females with a graduate degree.

\subsection{Patterns of reported performance in male-owner dominated business types}

Male-owner reported performance scores were highest among male owners with some college (5.57). In the male-owner dominated business types, male owners with a high school education reported higher performance scores than male owners with a college degree (5.5 vs. 4.9). Female owners with a high school education reported the lowest performance scores for the female owners. As the female owners gained more education, their reported performance scores increased. These findings raise questions about the schema of performance reporting the genders may be utilizing. While the gender-specific schema was not part of the present research, it merits further research among small business owners. The reported performance score in male-owner dominated business types was highest for female owners with some college, which equaled the responses from female owners with a graduate degree (6.0). The performance score in the male dominated businesses was lowest for females with a high school education (4.8) followed by males with a college degree (4.9).

\section{Discussion}

Fasci and Valdez (1998) suggested an industry-focused approach to examine the effect of gender and performance in small business. The research reported here followed this suggestion and focused on performance of firms in the service and retail industries. In the United States, 83 percent of female entrepreneurs operate in one of these two industries. Our research found that in these two industries, gender and education interact to impact reported firm performance, supporting previous non-industry specific research. When owner-gender dominant business types within the retail and services sectors examined performance-reporting patterns, the patterns point to new avenues for research. Our discussion is directed to the female-owner dominated business types first, followed by the results for the male-owner dominated business types.

\subsection{Female-owner dominant business types}

Within female owner-dominant business types (retail clothes and shoes, retail cards and gifts, retail computers, electronics and beauty shops) reported performance was highest among male-owners with a high school education (5.5) and lowest (4.4) for female owners with a graduate degree and males with a college degree. We suggest that socialization variables are possibly at play resulting in male owners with a college degree feeling over qualified for the 
job they are doing and thus rating their firm's performance low. Among female owners in the female owner dominant business types, females with only a high school diploma rated performance 5.1 and female college graduates rated firm performance 5.3. Further research should be done to probe the reasons for the decline in reported firm performance of maleowned firms operating in female-owner dominant business types as male owner's education moves from high school diploma to college degree. Future research is needed to probe why females with a high school education operating firms in female owner dominated business type's rate firm performance higher than females with the same education operating in male owner dominated business types (5.1 vs. 4.8). We suggest that the realm of operation (male or female- owner dominant) does have a bearing on the self-reported firm performance scores.

\subsection{Male-owner dominant business types}

Within male owner-dominant business types (financial services, personal services, bars, sales and repair services, retail housewares and hardware, retail sporting goods, and barber shops) the highest reported firm performance was from female owners with some college (6.0) while the lowest performance scores were among female owners with a high school education (4.8) and male owners with a college degree (4.9). Male owners with some college rated performance 5.6 followed by males with a high school education at 5.5 . These results may be manifesting high school educated females' feelings of inadequacy when operating a business type dominated by male owners. It is unclear why, among male owners, males with a college degree rated firm performance lowest. Males with a high school education report the same performance scores whether operating business types dominated by females or by males (5.5).

Female owners, on the other hand, would appear to view their lack of formal education beyond high school as more of a liability when they operate in the male dominated business types more than when they operate in the female dominated business types. When female owners with a high school education operate in the female dominated business types, performance was rated a 5.1 and when female owners with a high school education operated in the male dominated business types, they rate performance a 4.8 . This finding needs further exploration.

\subsection{Patterns of performance reporting}

The performance scores present new questions regarding possible schema the different genders use to evaluate firm performance. It might be expected that business owners, when asked to rate the performance of their personal entrepreneurial venture, would rate it relatively high. Veroff (1977), Travis (1982) and Poole and Langan-Fox (1993) stated that the genders do use different schema when evaluating personal career performance and this schema difference might be operating when the genders evaluate firm performance as well. Why do males with only a high school education report the highest performance scores in business types dominated by females, higher even than female owners with a college education or advanced degree? It is not clear if performance reporting is based on differences in 
socialization between the genders, resulting in feelings of insecurity or inadequacy among females with limited education. In businesses dominated by males, the female owners with a high school education report the lowest performance scores of all educational levels. More research needs to be done to explain these patterns of performance reporting between the genders.

While education does impact entry into an industry (Bates, 1995), does the consequence of education carry forward into firm performance evaluations? It may be that female business owners feel the pressure of competition in male owner dominated business types while males do not feel this same pressure when operating in business types dominated by females. The current research supports previous research findings, showing that firm performance is impacted by the interaction of gender and education of the owner (Cuba et al., 1983; Hisrich and Brush, 1984; Loscocco et al., 1991). Further research is necessary to determine if the gender of the owner is impacting firm performance as suggested by Litz and Folker (2002) or whether firm performance of the business is reported differently between the genders. The firm performance score may be due to some difference in schema each gender uses to evaluate performance or the score may have some connection to feelings of achievement, or lack of achievement, of education. In the retail and service industries, without regard to dominant owner business type, male owners with only a high school diploma report higher performance scores than female owners at any level of education (Table 3). This performance difference appears to be a gender issue that needs further investigation; females may be under-estimating the performance of their businesses, or males overestimate their firm's performance.

\section{Conclusions}

\subsection{Reported performance}

For businesses in the services and retail industries, the gender/education interaction significantly impacted reported performance scores. Thus, for our industry specific focus, results supported previous work. However, when respondents were grouped by dominant ownergender, the gender/education interaction did not significantly impact reported performance. In both male owner dominant and female owner business types there is no significant difference in education level of male or female owners and reported firm performance. Therefore, the type of business and whether male or female owners dominate it is not as important to reported performance as the industry of operation.

\subsection{Education and patterns of performance reporting}

The pattern of mean reported performance scores varied with educational level of business owner for both males and females. Fasci and Valdez (1998) found education had no influence on performance between male- and female-owned accounting practices. They suggested that this was due to the fact that all respondents in their study had a base educational level as all had CPA certification. Sonfield et al. (2001) found female respondents reporting a higher mean level of education than the male respondents in examination of the retail, service, and manufacturing sectors. No data was collected in their research on firm performance so 
no education/performance connection was examined. In the present study, female owners reported a slightly lower mean education score than male owners (2.50 vs. 2.53). Further research may reveal why female and male business owners with similar education report firm performance differently.

Our findings correspond with the findings of Veroff (1977), Travis (1982), and Poole and Langan-Fox (1993). There appear to be differences in firm performance perceptions between female and male business owners. In the overall sample of 267 retail and service businesses, mean performance scores were higher in male owned firms (5.14) than in female owned firms (5.06). In female-owner dominated business types, performance was rated higher in male owned firms among male and female owners with the same level of education until the females received a college degree. The female owners with a college degree rated firm performance higher than the male owners with the same education. Earning a college degree may have some relationship with evaluations of firm performance. In the male dominated business types, performance was highest in firms owned by females with some college or a graduate degree (6.0). Males with only a high school diploma rated their performance much higher than females with the same level of education (5.5 vs. 4.8). With at least some college, females rated their performance higher than the males. Reported business performance among female business owners is higher than male business owner's performance when the female owners have education beyond the high school level. For females owning a business in male owner dominated businesses, education beyond high school appears to improve reported business performance. Interestingly, females with some college report higher performance scores than females with a college degree when operating a firm in a male owner dominated business type.

Researchers investigating entrepreneurial gender differences and those working with small businesses will need to explore further the relationship between the business owner's educational level and their reported business performance levels. While education is important in today's society, it is in the smaller communities where business owner perseverance, time commitment and help from others may influence business performance as much as education. Thus, results might not be the same in large metropolitan areas.

Education alone is not a significant factor in small business performance. However, reported performance levels do rise with attainment of a college education for female owners in the business types investigated. For female entrepreneurs more education appears to translate into improved business performance.

For male entrepreneurs the pattern of performance reporting is not the same as for female entrepreneurs. Male entrepreneurs did not report improved performance with increased education. Male entrepreneurs with a high school education rated their performance higher than from any other educational level in the female dominated business types, and in maleowner dominated business types their performance was rated second highest behind male owners with some college. The high performance ratings of male owners with a high school education point to another avenue for future research. Males lacking education beyond high school may work very hard to ensure the success of their business. This commitment may be their only option for business success: hard work and perseverance in place of advanced 
education. Cases are numerous in which reported business success has come despite the entrepreneur having minimal formal education.

\section{Directions for Future Research}

This industry-focused study extends the findings of past gender focused entrepreneurial studies through an examination of the gender/education interaction on firm performance. This exploratory study addressed small firm performance within the service and retail industries and by dominant gender-owner business type. Results provide insight and raise fruitful questions for further study on the nature of owner-gender and small business performance. Findings will be beneficial to gender specialists and small firm owners and financiers. The need is great for further investigations of the impact of owner gender on reported firm performance.

\section{References}

Bates, T (1995). Self employment entry across industry groups. Journal of Business Venturing, 10, $143-157$.

Bates, T (1997). Unequal access: Financial institutions lending to black and white-owned small business start-ups. Journal of Urban Affairs, 19, 487-496.

Becker, M (1970). Sociometric location and innovativeness. American Sociological Review, 35, 267-304.

Bender, H (1980). Report on Women Business Owners. American Management Association.

Brown, K and S Ridge (2002). Moving into management: Gender segregation and its effect on managerial attainment. Women in Management Review, 17(7/8), 318-327.

Center for Women's Business Research. (2005). Top Facts about Women-Owned Businesses. http://www.womensbusinessresearch.org/topfacts.html.

Churchill, GA and D Iacobucci (2002). Marketing Research: Methodological Foundations. Mason, OH: South-Western Publishing.

Craig, JS, R Martin and P Horridge (1997). Apparel manufacturing business owners: A gender comparison. Clothing and Textiles Research Journal, 15(1), 1-11.

Cuba, R, D DeCenzo and A Anish (1983). Management practices of successful female business owners. American Journal of Small Business, 8(2), 40-46.

Dillman, D (2000). Mail and Telephone Surveys: The Tailored Design Method, Second Edition. New York, NY: John Wiley and Sons.

Dollinger, MJ (1985). Environmental contacts and financial performance of the small firm. Journal of Small Business Management, 23(1), 24-30.

Fasci, MA and J Valdez (1998). A performance contrast of male- and female-owned small accounting practices. Journal of Small Business Management, 36(3), 1-7.

Hisrich, RD and C Brush (1984). The woman entrepreneur: Management skills and business problems. Journal of Small Business Management, 22(1), 30-37.

Hudgens, G and L Fatkin (1985). Sex differences in risk taking: Repeated sessions on a computer simulated task. Journal of Psychology, 119(3), 1970-2206.

Kalleberg, AL and KT Leicht (1991). Gender and organizational performance: Determinants of small business survival and success. Academy of Management Journal, 34(1), 136-161.

Kirchoff, B (1994). Entrepreneurship and Dynamic Capitalism. Westport, CT: Praeger.

Levin, I, M Snyder and D Chapman (1988). The interaction of experiential and situation factors and gender in a simulated risky decision-making task. The Journal of Psychology, 122(2), 173-181. 
Litz, RA and CA Folker (2002). When he and she sell seashells: Exploring the relationship between management team gender-balance and small firm performance. Journal of Developmental Entrepreneurship, 7(4), 341-359.

Loscocco, K and J Robinson (1991). Barriers to small business success among women. Gender and Society, 5(4), 511-532.

Loscocco, K, J Robinson, R Hall, R and J Allen (1991). Gender and small business: An inquiry into women's relative disadvantage. Social Forces, 70(1), 65-85.

Marini, MM and MC Brinton (1984). Sex typing in occupational socialization. In Sex Segregation in the Workplace: Trends, Explanations, Remedies, BF Reskin (ed.). Washington D.C.: National Academy Press, pp. 192-232.

Poole, ME and J Langan-Fox (1993). Contrasting subjective and objective criteria as determinants of perceived career success: A longitudinal study. Journal of Occupational \& Organizational Psychology, 66(1), 39-55.

Powell, M and D Ansic (1997). Gender differences in risk behavior in financial decision-making: An experimental analysis. Journal of Economics Psychology, 18(6), 605-628.

Schmidt, RA and C Parker (2003). Diversity in independent retailing: Barriers and benefits-the impact of gender. International Journal of Retail \& Distribution Management, 31(8), 428-440.

Sexton, D and N Bowman-Upton (1990). Female and male entrepreneurs: Psychological characteristics and their role in gender related discrimination. Journal of Business Venturing, 5(1), 29-36.

Singh, SP, RG Reynolds and S Muhammad (2001). A gender-based performance analysis of micro and small enterprises in Java, Indonesia. Journal of Small Business Management, 39(2), 174-182.

Skinner, SD (1992). Female entrepreneurs in the retail trade: A study of personal and professional traits as they impact on business environments. International Review of Retail, Distribution and Consumer Research, 2(2), 183-195.

Sonfield, M, R Lussier, J Corman and M McKinney (2001). Gender comparisons in strategic decisionmaking: An empirical analysis of the entrepreneurial strategy matrix. Journal of Small Business Management, 39(2), 165-173.

Small Business Administration Office of Advocacy (2003, March). Dynamics of Women-Operated Sole Proprietorships, 1990-1998. Washington D.C.

Travis, CB (1982). Sex comparisons on causal attributions: Another look at the null hypothesis. Sex Roles, 8(4), 375-380.

U.S. Department of Labor (2005). Women in the Labor Force in 2004. http://www.dol.gov/wb/ factsheets/QF-laborforce-04.htm.

U.S. Women's Chamber of Commerce (2005). The New Generation of Leadership for Women. http://www.sblink.us/html/uswcc-about.aspx.

Veroff, J (1977). Process vs. impact in men's and women's achievement motivation. Psychology of Women Quarterly, 1(3), 283-294.

Venkatraman, N and V Ramanujam (1986). Measurement of business performance in strategy research: A comparison of approaches. Academy of Management Review, 11, 801-814.

Wirth, L (2001). Breaking Through the Glass Ceiling. Geneva, International Labour Office. 
Copyright of Journal of Developmental Entrepreneurship is the property of World Scientific Publishing Company and its content may not be copied or emailed to multiple sites or posted to a listserv without the copyright holder's express written permission. However, users may print, download, or email articles for individual use. 